\title{
Dry Matter and Macronutrient Accumulation in Digitaria insularis Biotypes Susceptible and Resistant to Glyphosate
}

\author{
Anne Elise Cesarin ${ }^{1}$, Pedro Figueiredo Rocha Barbosa Martins ${ }^{1}$, Arthur Arrobas Martins Barroso ${ }^{1}$, \\ Willians César Carrega ${ }^{1}$, Pedro Luis da Costa Aguiar Alves ${ }^{1} \&$ Silvano Bianco $^{1}$ \\ ${ }^{1}$ Weed Sciences Laboratory, Sao Paulo State University, Jaboticabal, SP, Brazil \\ Correspondence: Anne Elise Cesarin, Weed Sciences Laboratory (LAPDA), University of Sao Paulo, \\ UNESP/FCAV, Via de Acesso Prof. Paulo Donato Castellane s/n, 14884-900, Jaboticabal, São Paulo, Brazil. Tel: \\ 55-163-209-7100. E-mail: annecesarin@gmail.com
}

Received: November 27, 2018

Accepted: January 9, 2019

Online Published: March 15, 2019

doi:10.5539/jas.v11n4p151

URL: https://doi.org/10.5539/jas.v11n4p151

\begin{abstract}
Herbicide resistant is associated with morphological, physiological and metabolic alterations in weeds. These alterations may reflect changes in the nutritional status of resistant plants and their growth it can be inferred in greater adaptability and competitive ability of the resistant biotypes. Thus, the objective of this research was to determine the dry matter and macronutrient accumulation and distribution by glyphosate-resistant and susceptible plants of Digitaria insularis (sourgrass), growing under mineral nutrition standard conditions. The experimental design was completely randomized, with eleven treatments and four replicates. The treatments consisted of evaluation periods at 15, 30, 45, 60,75, 90, 105, 120, 135, 150 and 165 days after emergence (DAE). The average time for maximum theoretical accumulation (PtMax) and for inflection points of dry mass and macronutrient were lower for susceptible (133 DAE; 99 DAE) than for resistant biotype (141 DAE; 105 DAE). However, considering the average time obtained by susceptible, dry mass $(\mathrm{g})$ and macronutrients $(\mathrm{mg})$ accumulation was always higher for resistant biotype. The decreasing sequence of nutrient accumulation was similar for both sourgrass biotypes: $\mathrm{K}, \mathrm{N}, \mathrm{Ca}, \mathrm{Mg}, \mathrm{P}$ and $\mathrm{S}$.
\end{abstract}

Keywords: growth analysis, mineral nutrition, resistance, sourgrass

\section{Introduction}

One of the factors that presents high relevance for agricultural production is herbicide resistant biotypes in crop areas, which may be influenced by the interaction of ecological and biological characteristics of the species, genetic base and agronomical factors. The factor that contributes most for a resistant weed selection is the selective pressure exerted by the repetitive herbicide usage or different herbicide (with same site of action) and production systems that do not practice crop rotation (monoculture areas) and herbicide rotation frequently (Vencill et al., 2012; Renton et al., 2014).

Glyphosate is an intensely used herbicide in many production systems and is acts upon the enzyme EPSPs (5-enolpyruvylshikimate-3-phosphate), in aromatic amino acids synthesis route and shikimic acid. Nowadays, there are forty-three weed species confirmed to be resistant to glyphosate in World. In Brazil there are eight: Amaranthus palmeri; Chloris elata; Conyza bonariensis, C. canadensis and C. sumatrensis; D. insularis; Eleusine indica; Lolium perenne ssp. multiflorum (Heap, 2018).

The $D$. insularis species is a perennial plant that is highlighted by the formation of rhizome and clumps, with slow initial growth and posterior exponential dry matter accumulation (Machado et al., 2008; Carvalho et al., 2013; Marques et al., 2014). Such factors is related to its aggressiveness as a weed species and may provide high competitiveness to the species for natural resources, among them, nutrients present in the soil. Competition for nutrients is one of the main ecological factors that may affect crop production.

The mechanisms that are related to this species resistance occur through the reduced absorption and translocation of herbicide, glyphosate metabolizing alterations (rapid degradation to AMPA, glyoxylate and sarcosin) and genic mutation (two alterations of amino acids in positions 182 and 310 on EPSPs, consisting of a prolin substitution for treonin and a tirosin for cistein, respectively) (Carvalho et al., 2012). 
Resistance to herbicides may or not establish a competitive disadvantage on resistant populations (Travlos, 2013), and to assure its evolutive success based on survival, competitive ability and reproductive ability, in which the most apt individual supply the higher number of descendants and contributes, in so, with a higher proportion of its genes in the gene pool of the population (Warwick \& Black, 1994). Basic studies as the nutrient absorption march and nutrient usage by weed species, regarding Bianco et al. (2015), are fundamental to understand the behavior of individuals and give subsidy for predictions of its success as weed regarding new agricultural practices.

In this way, to analyze differences between resistant and susceptible biotypes through basic studies about their biology, especially those factors related to mineral nutrition, aim to comprehend the behavior and adaptation of these individuals in the environment, once this may reflect higher nutritional requirement and plant growth. Facing this, the aim of this work is to determine the accumulation and distribution of dry matter and macronutrients in resistant and susceptible biotypes of $D$. insularis.

\section{Materials and Method}

\subsection{Plant Material and Herbicide Resistance Confirmation}

Sourgrass seeds were collected from two accessions in Brazil (November 2014) in at least 40 plants: a natural field $\left(21^{\circ} 37^{\prime} 58^{\prime \prime} \mathrm{S}\right.$ and $\left.48^{\circ} 28^{\prime} 56^{\prime \prime} \mathrm{W}\right)$ and a grain production area $\left(21^{\circ} 15^{\prime} 22^{\prime \prime} \mathrm{S}\right.$ and $\left.48^{\circ} 18^{\prime} 58^{\prime \prime} \mathrm{W}\right)$ from São Paulo State (SP). The biotype from the natural field, designated as susceptible plant (hereafter referred to as biotype S), were collected in isolated area, without herbicide application. While seeds of biotype under suspicion of being resistant (hereafter referred to as biotype R) were collected in grain production area from plants surviving applications of glyphosate (720 g a.e. $\mathrm{ha}^{-1}$ ) according to Burgos et al. (2013). Besides that, glyphosate-resistant sourgrass populations from this grain production area were studied in previous research performed by Carvalho et al. (2012).

To confirm biotypes resistance to glyphosate, a dose-response curve experiment was performed by regression methods using a nonlinear regression through logistic equation. It was verified that the resistant biotype showed a 3.5 resistance factor (data not shown). This factor indicates that the dosage needed to reduce in $50 \%$ the dry matter production of the resistant biotype was 3.5 times higher than the same reduction in dry matter of the susceptible biotype.

\subsection{Experimental Area, Treatments and Experimental Design}

The experiment was conducted in greenhouse environment during March to September of 2015. Monthly meteorological data collected during the experiment are shown in Table 1.

Table 1. Climactic data obtained during the experiment conduction period

\begin{tabular}{llllll}
\hline Month & Tmax & Tmin & RH & ND & Insolation (h) \\
\hline March & 32.4 & 19.2 & 79.3 & 21 & 148.3 \\
April & 33.2 & 16.9 & 24 & 7.0 & 234.5 \\
May & 28.6 & 15.2 & 20.1 & 8.0 & 180.9 \\
June & 29.1 & 13.7 & 18.1 & 2.0 & 239.3 \\
July & 29.5 & 11.5 & 19.3 & 5.0 & 189.4 \\
August & 32.9 & 14.5 & 20.7 & 2.0 & 283.4 \\
September & 33.7 & 15.3 & 22.5 & 12.0 & 208.5 \\
\hline
\end{tabular}

Note. Tmax: maximum temperature in the interior of greenhouse. Tmin: minimum temperature; RH: relative humidity, collected inside the greenhouse. ND: number of days with rain.

Data collected by FCAV/UNESP Agroclimatological Station.

The seeds of both biotypes were sown in plastic vases with $8 \mathrm{~L}$ capacity, filled with washed river sand, previously sifted. Vases were irrigated with complete Hoagland and Arnold (1950) solution, receiving 25\% of original concentration during the first 7 days and, posteriorly, $100 \%$ until the end of the experimental phase.

Experimental design was completely randomized, with four replications. Treatments consisted of destructive evaluations by harvesting of the plants at 15, 30, 45, 60,75, 90, 105, 120, 135, 150 and 165 days after emergence, corresponding to 11 harvesting periods. In every harvest period, the plants were harvested and separated into leaves, stems and roots. After that, all the harvested material was submitted to rapid immersion into neutral 
detergent solution, washed through immersion into distilled water and, finally, immersion into deionized water (Sarruge \& Haag, 1974).

Soon after, the aboveground parts and roots were put to dry in a air circulation oven at $70{ }^{\circ} \mathrm{C}$, during 48 hours, for then to determine the dry matter of each part. After weighting, the material was triturated in Willey mini mill using 40 mesh sift for macronutrient determination.

Total nitrogen $\left(\mathrm{N}_{\text {total }}\right)$ and phosphorus $(\mathrm{P})$ were determined through semimicro method Kjedahl and colorimetric method of phosphovanado-molybdic acid, respectively (Sarruge \& Haag, 1974). For potassium (K), calcium (Ca) and magnesium (Mg) extraction, it was used the method described by Jorgensen (1977), through atomic absorption spectrophotometry. Sulphur (S) was determined through the turbimetric method described by Vitti (1989).

\subsection{Assessed Variables and Statistical Analysis}

Through the nutrient rates obtained along the plant cycle, it was determined the variation amplitude of each total rate of nutrient by the highest and the lowest values observed. The nutrient accumulation for each of the parts of the plant were attained multiplying the nutrient rate by correspondent dry matter. Total accumulation was obtained by the sum of the accumulation of different plant parts, as for the total plant rate was obtained by the relation of total accumulation of the plant and correspondent total dry matter.

The inflexion points (PtInf) and theoretical total accumulation (PtMax) of dry matter and macronutrients were determined by the exponential equation $y=\exp \left(a+b \cdot x+c \cdot x^{2}\right)$, in which $y$ is the dry matter accumulation and macronutrient, and $\mathrm{x}$ is the days after emergence (Carvalho et al., 2013). The regression analysis was calculated using OriginPro 8.5 .

\section{Results}

\subsection{Dry Matter Parameters}

\subsubsection{Dry Matter Accumulation}

At the initial phase of the experiment (from 15 to $60 \mathrm{DAE}$ ), the accumulation of dry matter content for both biotypes was slow, with mean accumulation of $0.4 \mathrm{~g}$ per plant for biotype $\mathrm{R}$ and $0.2 \mathrm{~g}$ for biotype $\mathrm{S}$ (Figure 1). From the $60 \mathrm{DAE}$, the plant growth for both biotypes increased, reaching the maximum dry matter allocation (PtMax) at $140 \mathrm{DAE}$, with theoretical value of $4.5 \mathrm{~g}$ of dry matter per plant $(\mathrm{R})$ and at $133 \mathrm{DAE}$ with $3.3 \mathrm{~g}$ per plant of dry matter (S). The inflexion point (PtInf) obtained for resistant plants was at 101 DAE with theoretical mean accumulation of $3.5 \mathrm{~g}$ per plant, and for biotype $\mathrm{S}$, was at $97 \mathrm{DAE}$ with theoretical mean accumulation of $2.5 \mathrm{~g}$ per plant.

At the end of the experiment, the maximum accumulation was of 3.8 (biotype R) and 2.24 (biotype S) g per plant. It is important to emphasize that the mean dry matter accumulation of biotype $\mathrm{R}$ was $40 \%$ higher than that of susceptible one.

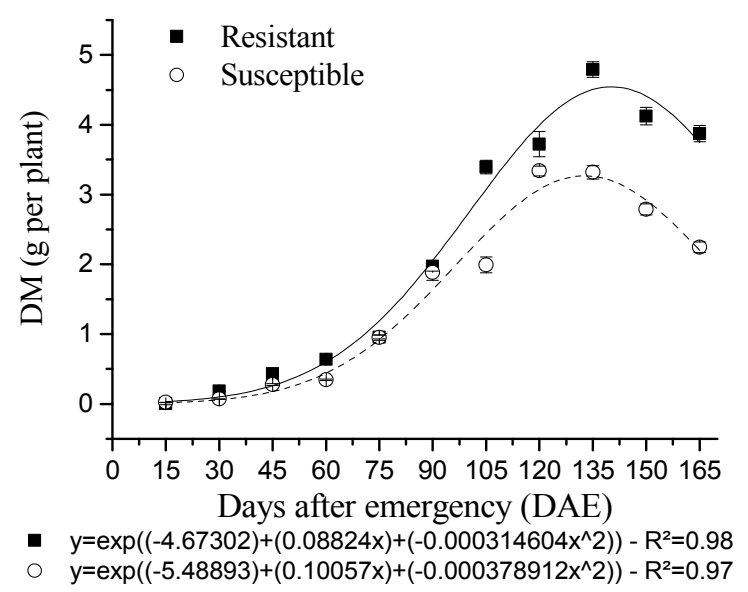

Figure 1. Dry matter accumulation (DM) of resistant (R) and susceptible (S) D. insularis biotypes, grown in standardized conditions of mineral nutrition. Means \pm Standard Error $(n=5)$ 


\subsubsection{Dry Matter Allocation}

Plants of both biotypes have shown dry matter distribution differentiated during all the evaluation periods (Figure 2). The biomass increment during all the experiment was higher in the roots related to leaves and stems, for both biotypes. However, the roots of biotype $\mathrm{S}$ accumulated more mass than those of biotype R during almost every period. The mean accumulation on roots, during all the cycle, for both biotypes was of $53 \%$ and $60 \%$, respectively.

Regarding dry matter allocation on leaves, during all the experimental period, it is noted that biotype $\mathrm{R}$ shows higher allocation than the susceptible one, except for the 60 DAE period. During the second half of the cycle, the mean accumulation on leaves was diminished related to the first half for both biotypes.

The percentage of dry matter on the stems along the cycle was also higher for biotype R than that of biotype S, except for the 60 and $75 \mathrm{DAE}$. Beside, observing the acquired data it is possible to see that at $30 \mathrm{DAE}$, comparing the distribution among the aboveground parts, the dry matter allocation was higher on the leaves $(22 \%)$ than in the stems $(18 \%)$. From the $30 \mathrm{DAE}$ on occurred an inversion and the stems show a higher dry matter accumulation.
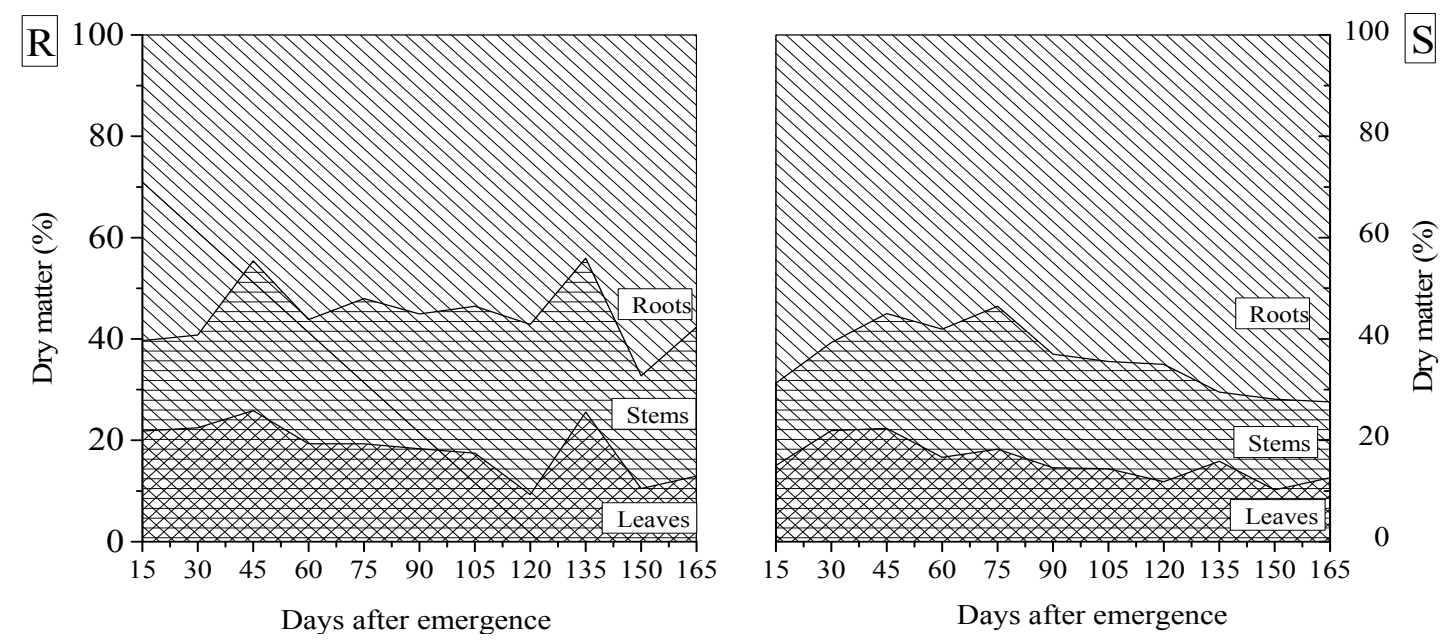

Figure 2. Percentage distribution of accumulated dry matter in different parts of resistant (R) and susceptible (S) D. insularis biotypes

\subsection{Macronutrients Evaluations}

\subsubsection{Amplitude of Nutrient Concentration}

The valor amplitude of nutrient concentration were only different for $\mathrm{K}, \mathrm{Ca}$ and $\mathrm{Mg}$ (Figure 3). The amplitude of $\mathrm{K}$ rates was most elevated for biotype $\mathrm{R}$, and for $\mathrm{Ca}$ and $\mathrm{Mg}$, those were slightly superior for biotype $\mathrm{S}$. In this way, the efficiency for $\mathrm{K}$ requirement per biomass unity accumulated was higher for biotype $\mathrm{R}$, and for $\mathrm{Ca}$ and $\mathrm{Mg}$ requirement, slightly higher for biotype S. 


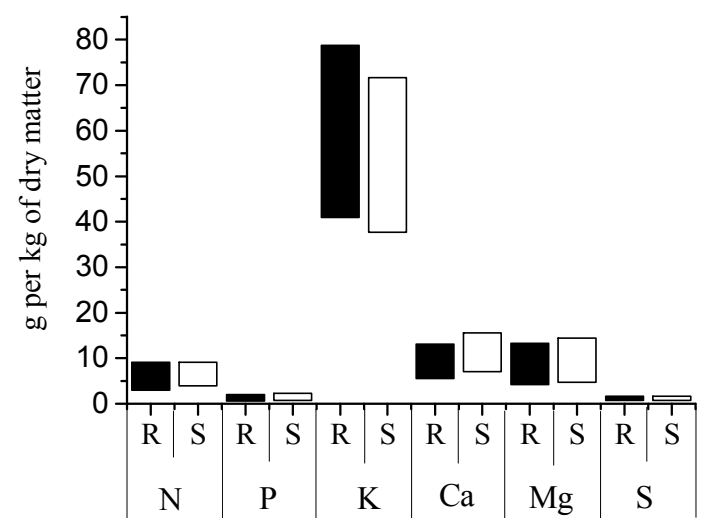

Figure 3. Amplitude of variation of total rates of nitrogen $(\mathrm{N})$, phosphorus $(\mathrm{P})$, potassium $(\mathrm{K})$, calcium $(\mathrm{Ca})$, magnesium $(\mathrm{Mg})$ and sulphur $(\mathrm{S})$ of resistant $(\mathrm{R})$ and susceptible $(\mathrm{S})$ D. insularis biotypes

\subsubsection{Macronutrient Accumulation}

In general, after the $75 \mathrm{DAE}$, the accumulation was more intense for every nutrient. The sequence of higher macronutrient accumulation on sourgrass biotypes was K, N, Ca, Mg, P and S (Figure 4).

$\mathrm{N}$ accumulation was variable among the biotypes during the experimental period. Until $45 \mathrm{DAE}$, the nutrient content was 50\% higher in biotype R. However, between 60 and 105 DAE, the inverse occurs, and the biotype S exhibits a larger accumulation of N (30\%). After 120 DAE, the levels are similar for the two biotypes.

The analyses revealed that the highest accumulation of $\mathrm{P}, \mathrm{K}, \mathrm{S}, \mathrm{Mg}$ and $\mathrm{Ca}$ were observed in biotype R. The difference between biotypes was around 20\% during the first part of the cycle (90 DAE) and almost 50\% during the second part (90 to $160 \mathrm{DAE}$ ).

PtMax found in biotype R for nutrients N, P, K, Ca, Mg and S were (per plant): at 140 DAE (101.9 mg), 143 DAE (23 mg), 139 DAE (580 mg), 135 DAE (146 mg), 145 DAE (118 mg) and 157 DAE (22 mg), respectively. For biotype S, the PtMax of nutrients N, P, K, Ca, Mg and S were: at 139 DAE (69.3 mg), 131 DAE (14 mg), 124 DAE (297 mg), 135 DAE (114 mg), 131 DAE (77 mg) and 142 DAE (12 mg), respectively. After reaching PtMax, the accumulation decreases in function of senescence of leaves due to lower nutrient requirement by the plants.

Values of PtInf obtained for resistant plants were: 120 DAE (N), 106 DAE (P), 106 DAE (K), 118 DAE (S), 103 DAE (Ca) and 110 DAE $(\mathrm{Mg})$; and for susceptible ones were: 106 DAE $(\mathrm{N}), 99$ DAE $(\mathrm{P}), 86$ DAE $(\mathrm{K}), 107$ $\operatorname{DAE}(\mathrm{S}), 105 \mathrm{DAE}(\mathrm{Ca})$ and $102 \mathrm{DAE}(\mathrm{Mg})$.

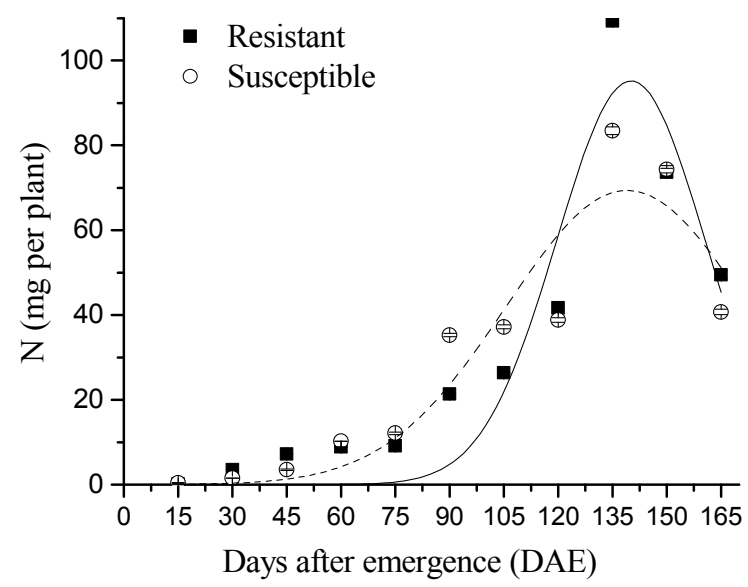

- $y=\exp \left((-18.85997)+(0.33434 x)+\left(-0.00119 x^{\wedge} 2\right)\right) \quad-R^{2}=0.86$ ○ $y=\exp \left((-4.44485)+(0.12495 x)+\left(-0.000449472 x^{\wedge} 2\right)\right)-R^{2}=0.84$

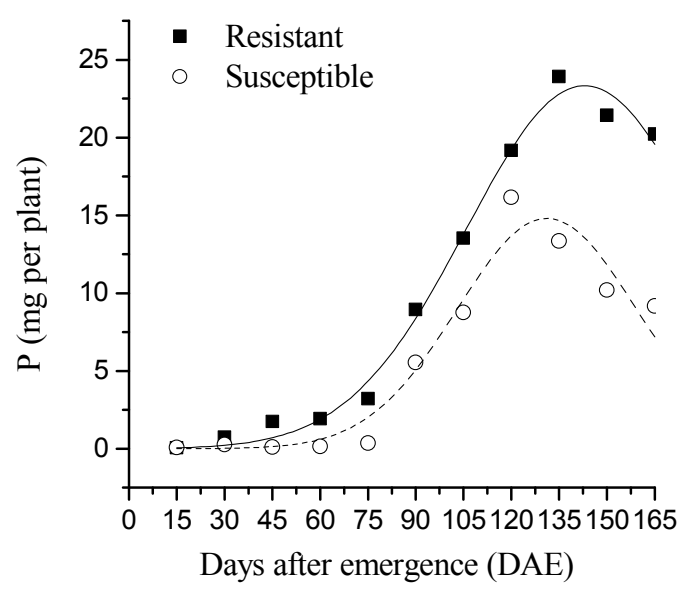

- $y=\exp \left((-4.30644)+(0.10431 \mathrm{x})+\left(-0.000364776 \mathrm{x}^{\wedge} 2\right)\right) \quad-\mathrm{R}^{2}=0.99$ O $\mathrm{y}=\exp \left((-8.18475)+(0.16591 \mathrm{x})+\left(-0.000632526 \mathrm{x}^{\wedge} 2\right)\right)-\mathrm{R}^{2}=0.94$ 

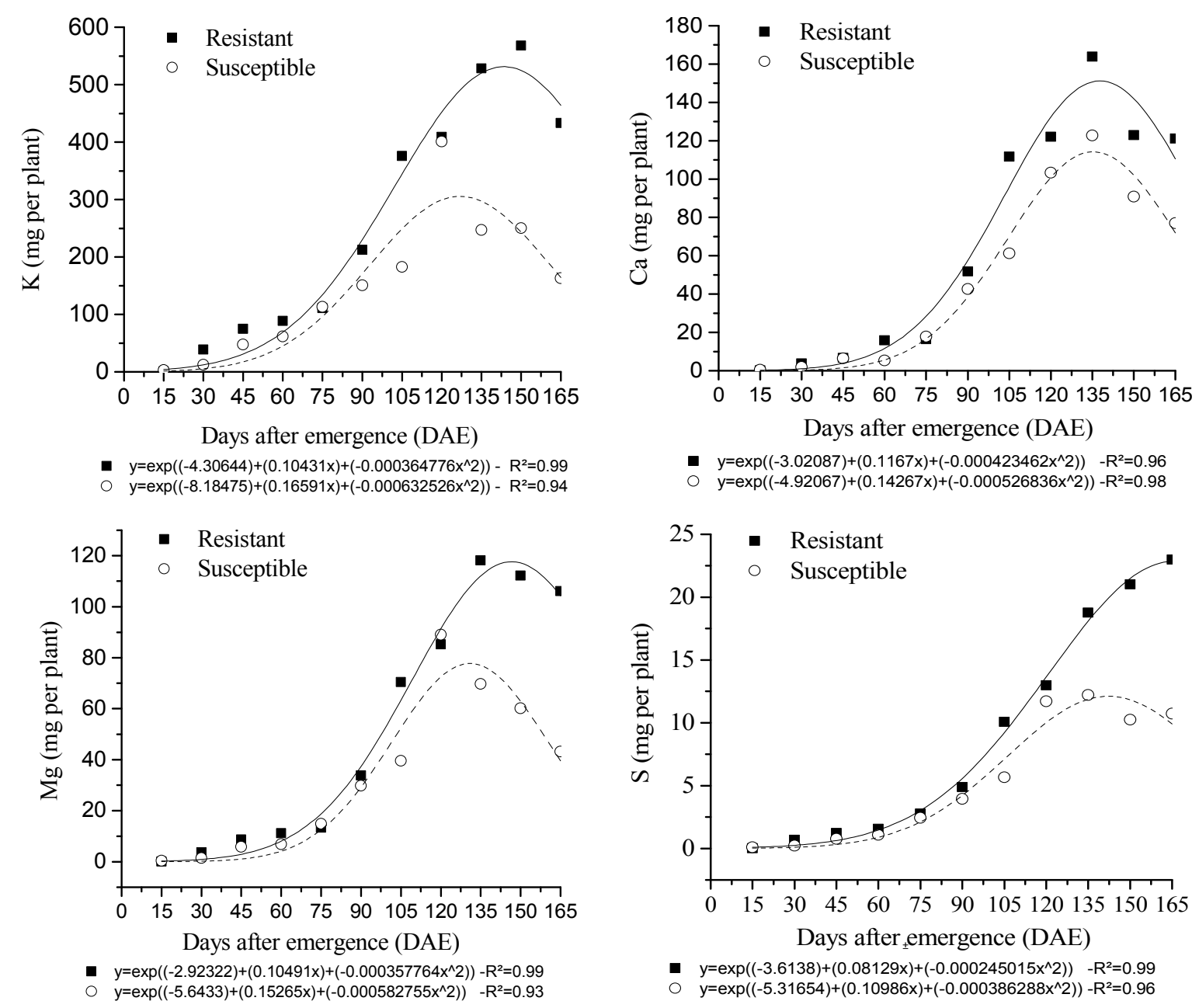

Figure 4. Macronutrient accumulation (N, P, K, Ca, Mg and $\mathrm{S}$ ) of of resistant (R) and susceptible (S) D. insularis biotypes. Means \pm Standard Error $(\mathrm{n}=5)$

Analyzing the mean between points of inflexion of macronutrients obtained by each biotype, the value was obtained at 110 DAE (biotype R) and 101 DAE (biotype S). Regarding the value of 101 DAE of both biotype, the mean theoretical accumulation for resistant and susceptible plants were, respectively, 1.3 and $1.4 \mathrm{mg}(\mathrm{N}), 0.4$ and $0.3 \mathrm{mg}(\mathrm{P}), 10$ and $4 \mathrm{mg}(\mathrm{K}), 3$ and $2(\mathrm{Ca}), 1.9$ and $1.6 \mathrm{mg}(\mathrm{Mg})$ and 0.3 and $0.2 \mathrm{mg}(\mathrm{S})$. Although PtInf of biotype $\mathrm{S}$ being reached 9 days before the biotype $\mathrm{R}$, the theoretical accumulation of macronutrients (except for nitrogen) was lower when compared to the biotype $\mathrm{R}$.

\section{Discussion}

The differences in sourgrass plants was also described by Martins et al. (2016), where resistant biotypes show faster growth and assimilation rate (increment of dry matter in function of foliar area) higher than the susceptible biotype. The assimilation rate found in resistant plant indicates that the biotype is most adapted to high levels of irradiance during the initial development stage due to more efficient photosynthetic system. Barroso et al. (2015) evidences lower distances of the vascular bundles for resistant biotypes. Leaves with near vascular bundles have lesser hydraulic resistance and high photosynthetic rates, therefore, higher photosynthesis rates in resistant plants may explain its faster development when compared to susceptible ones. In other experiments was also observed higher photosynthetic rates in resistant biotypes (Carvalho et al., 2012).

By the data presented, roots of biotypes resistant and susceptible were the organs which present higher matter accumulation in the plant, in the analyzed period. Biomass production data upon different parts in this work differ from those analyzed by Pereira et al. (2017), where the susceptible plants accumulated more dry leaf mass, while the resistant ones accumulated more roots dry mass, and by Machado et al. (2008), in which sourgrass leaves (without distinction of herbicide-resistant plants) were the main dry matter allocation site. Carvalho et al. 
(2013), in which leaves are the main organs accumulating dry mass in the first half of sourgrass life cycle (without distinction of herbicide-resistant plants), while stems become the most important ones in the second half, from 77 DAE on.

The patterns of biomass allocation in plants may be influenced by some factors like growth environment (temperatures, irradiance levels, nutrients and drought), plant size and competition, among others. Environmental conditions, like low temperatures and low nutrients, and drought show increased allocation to roots at the expense of stem and, especially, of leaf biomass (Poorter et al., 2011). While high planting densities generally invoke increased allocation to stems at the expense of rootsandor leaves. Wilt and yellow symptoms typically under low nutrient or drought condition, were not observed in this work. So, identification of the potential mechanisms responsibles for biomass allocation, mainly under different environments or stress conditions (temperature, drought, competition, irradiance levels), will help us to understand the adaptations, evolution or establishment of these plants on different environments.

As observed for nutrient parameters, nutrient $\mathrm{K}$ presented the largest difference between the biotypes. K nutrient is the most frequently limiting to plant growth and crop yielding. It is an essential nutrient in many processes, as in stomatal pore opening and closing (Hosy et al., 2003) acts in the activation or as cofactor in many enzymatic systems (Jin et al., 2011), protein synthesis, carbohydrate metabolism, sugar transport, in transference and usage of energy (Römheld \& Kirkby, 2010).

The capacity of photosynthesis in plants changes drastically in answer to different $\mathrm{K}$ supplies. When it occurs its deficiency, photosynthesis and ATP production rate diminish (Weng et al., 2007). During ATP production, the electrical charge balance is maintained by $\mathrm{K}$ ions, which is important to maximize the ATP production during photosynthesis (Alberts et al., 2002). As cited before, higher photosynthetic rates were found in resistant biotypes (Carvalho et al., 2012, Barroso et al., 2015; Martins et al., 2016), which may be closely related to the higher $\mathrm{K}$ requirement for biotype $\mathrm{R}$.

Maximum theoretical accumulation (PtMax) and inflexion (PtInf) points of dry matter and macronutrients were lower for susceptible biotype, being these at $133 \mathrm{DAE}$ and $99 \mathrm{DAE}$, respectively, when compared to the resistant biotype (141 DAE; 105 DAE), however, considering the lower time period (133 DAE and 99 DAE), dry matter accumulation and nutrient accumulation was higher in the resistant plants.

The value of PtInf may be understood as the day in which the daily accumulation of macronutrients in the plant reached the maximum value, being the daily absorption rate crescent until this moment (Carvalho et al., 2007). The values of inflexion found in both biotypes may coincide with the period in which maize crops start its maturation stage (around $100 \mathrm{DAE}$, variable regarding cultivar and sowing), period in which occurs elevated absorption rates of macronutrients by the plants, which may cause prejudices to the crop yield due the competition between crops and weeds. However, as the resistant weeds accumulate more biomass and macronutrients (in the same period), this biotype may become more competitive for resources and cause more damage to the mentioned crops. Generally, an increase in one kilogram of weed growth corresponds to a reduction in one kilogram of crop growth (Rao, 2000). Therefore, it is essential to prevent further yield losses by limiting seed movement and vegetative reproduction, and adopt strategies that decrease herbicide selection pressure, such as herbicide rotation, herbicide mixture, cover crops and tillage.

The lack of a fitness penalty in the absence of glyphosate would complicate the long-term management of glyphosate-resistant sourgrass because periods of alternate methods of management would not be expected to reduce the resistant trait frequency (Preston et al., 2009), and it control becomes even more difficult and costly. In this way, applying different herbicide modes of action and monitoring glyphosate-resistant sourgrass populations is essential to provide efficiency of control. In addition, it is fundamental to apply the herbicide in initial stages of growth, in order to prevent seeds and vegetative propagation of this population in the area, and consequently crop yield reductions.

\section{Conclusion}

Results allow concluding that the resistant biotype presents greater accumulation of total biomass and macronutrients, which may reflect a greater competitive advantage by the resources of the environment in relation to the susceptible biotype.

\section{Acknowledgements}

The authors would like to thank the research funding agencies CAPES for the scholarships granted to the post-graduate students participating in the study, and to CNPq for the concession of researcher funding for Alves. 


\section{References}

Alberts, B., Johnson, A., Lewis, J., Raff, M., Roberts, K., \& Peter Walter, P. (2002). Molecular biology of the cell (4th ed.). New York: Garland Science.

Barroso, A. A. M., Galeano, E., Albrecht, A. J. P., Reis, F. C., \& Victoria Filho, R. (2015). Does sourgrass leaf anatomy influence glyphosate resistance? Comunicata Scientiae, 6(4), 445-453. https://doi.org/10.14295/ cs.v6i4.1124

Bianco, S., Carvalho, L. B., Bianco, M. S., \& Yamauchi, A. K. F. (2015). Crescimento e nutrição mineral de Urochloa arrecta. Planta Daninha, 33(1), 33-40. https://doi.org/10.1590/S0100-83582015000100004

Burgos, N., Tranel, P. G., Strebig, J. C., Davis, V. M., Shaner, D., Norsworthy, J. K., \& Ritz, C. (2013). Review: Confirmation of resistance to herbicides and evaluation of resistance levels. Weed Science, 66, 4-20. https://doi.org/10.1614/WS-D-12-00032.1

Carvalho, L. B., Bianco, M. S., \& Bianco, S. (2013). Accumulation of dry mass and macronutrients by sourgrass plants. Planta Daninha, 31(4), 785-792. https://doi.org/10.1590/S0100-83582013000400004

Carvalho, L. B., Alves, P. L., González-Torralva, F., Cruz-Hipolito, H. E., Rojano-Delgado, A. M., De Prado, R., ... Castro, M. D. (2012). Pool of resistance mechanisms to glyphosate in Digitaria insularis. Journal Agricultural Food Chemistry, 60(2), 615-622. https://doi.org/10.1021/jf204089d

Carvalho, L. B. I, Bianco, S., Pitelli, R. A., \& Bianco, M. S. (2007). Estudo comparativo do acúmulo de massa seca e macronutrientes por plantas de milho var. BR-106 e Brachiaria plantaginea. Planta Daninha, 25(2), 293-301. https://doi.org/10.1590/S0100-83582007000200008

Heap, I. (2018). The International Survey of Herbicide Resistence Weeds. Retrieved from http://www. weedscience.com

Hoagland, D. R., \& Arnon, D. J. (1950). The water culture method of growing plants without soil (Circular, 347). Berkeley: University of California.

Hosy, E, Vavasseur, A., Mouline, K., Dreyer, I., Gaymard, F., Porée, F., ... Sentenac, H. (2003). The Arabidopsis outward $\mathrm{K}^{+}$channel GORK is involved in regulation of stomatal movements and plant transpiration. Proceedings of the National Academy of Sciences, 100(9), 5549-5554. https://doi.org/10.1073/ pnas. 0733970100

Jin, S. H., Huang, J. Q., Li, X. Q., Zheng, B. S., Wu, J. S., Wang, Z. J., .. Chen, M. (2011). Effects of potassium supply on limitations of photosynthesis by mesophyll diffusion conductance in Carya cathayensis. Tree Physiology, 31(10), 1142-1151. https://doi: 10.1093/treephys/tpr095

Jorgensen, S. S. (1977). Metodologia utilizada para análises químicas de rotina: Guia analítico. Piracicaba: CENA.

Machado, A. F. L., Meira, R. M. S., Ferreira, L. R., Ferreira, F. A., Tuffi Santos, L. D., Fialho, C. M. T., \& Machado, M. S. (2008). Caracterização anatômica de folha, colmo e rizoma de Digitaria insularis. Planta Daninha, 26(1), 1-8. https://doi.org/10.1590/S0100-83582008000100001

Marques, B. S., Silva, A. P. P., Lima, R. S. O., Machado, E. C. R., Gonçalves, M. F., \& Carvalho, S. J. P. (2014). Growth and development of sourgrass based on days or thermal units. Planta Daninha, 32(3), 483-490. https://doi.org/10.1590/S0100-83582014000300003

Martins, J. F., Barroso, A. A. M., Carvalho, L. B. C., Cesarin, A. E., Amaral, C. L., Nepomuceno, M. P., ... Alves, P. L. C. A. (2016). Plant growth and genetic polymorphism in glyphosate-resistant sourgrass (Digitaria insularis L. Fedde). Australian Journal of Crop Science, 10(10), 1466-1473. https://doi.org/ 10.21475/ajcs.2016.10.10.p7761

Pereira, G. R., Costa, N. V., Moratelli, G., \& Rodrigues-Costa, A. C. P. (2017). Growth and development of Digitaria insularis biotypes susceptible and resistant to glyphosate. Planta Daninha, 35, e017160505. https://doi.org/10.1590/s0100-83582017350100025

Poorter, H., Niklas, K. J., Reich, P. B., Oleksyn, J., Poot, P., \& Mommer, L. (2012). Biomass allocation to leaves, stems and roots: Meta-analyses of interspecific variation and environmental control. New Phytologist, 193, 30-50. https://doi.org/10.1111/j.1469-8137.2011.03952.x 
Preston, C., Wakelin, A. M., Dolman, F. C., Bostamam, Y., \& Boutsalis, P. (2009). A decade of glyphosate-resistant Lolium around the world: Mechanisms, genes, fitness, and agronomic management. Weed Science, 57(4), 435-441. https://doi.org/10.1614/WS-08-181.1

Rao, S. (2000). Principles of weed science (2nd ed.). New York: Science Publishers.

Renton, M., Busi, R., Neve, P., Thornby, D., \& Vila-Aiub, M. (2014). Herbicide resistance modelling: Past, present and future. Pest Management Science, 70(9), 1394-1404. https://doi.org/10.1002/ps.3773

Romheld, V., \& Kirkby, E. A. (2010). Research on potassium in agriculture: Needs and prospects. Plant Soil, 335 , 155-180. https://doi 10.1007/s11104-010-0520-1

Sarruge, J. R., \& Haag, H. P. (1974). Análises químicas em plantas. Piracicaba: ESALQ/USP.

Takano, H. K., Oliveira Jr., R. S., Constantin, J., Mangolim, C. A., Machado, M. F. P. S., Bevilaqua, M. R. R. (2018). Spread of glyphosate-resistant sourgrass (Digitaria insularis): Independent selections or merely propagule dissemination? Weed Biology and Management, 18(3), 50-59. https://doi.org/10.1111/wbm.12143

Travlos, I. S. (2013). Competition between accase-inhibitor resistant and susceptible sterile wild oat (Avena sterilis) biotypes. Weed Science, 66(1), 26-31. https://doi.org/10.1614/WS-D-12-00065.1

Vencill, W., Nichols, R., Webster, T., Soteres, J., Mallory-Smith, C., Burgos, N., ... McClelland, M. (2012). Herbicide resistance: toward an understanding of resistance development and the impact of herbicide-resistant crops. Weed Science, 60(SP1), 2-30. https://doi:10.1614/WS-D-11-00206

Vitti, G. C. (1989). Avaliação e interpretação do enxofre no solo e na planta. Jaboticabal: FUNEP.

Warwick, S. I., \& Black, L. D. (1994). Relative fitness of herbicide-resistant and susceptible biotypes of weeds. Phytoprotection, 75(4), 37-49. https://doi.org/10.7202/706070ar

Weng, X. Y., Zheng, C. J., Xu, H. X., \& Sun, J. Y. (2007). Characteristics of photosynthesis and functions of the water-water cycle in rice (Oryza sativa) leaves in response to potassium deficiency. Physiologia Plantarum, 131(4), 614-621. https://doi.org/10.1111/j.1399-3054.2007.00978.x

\section{Copyrights}

Copyright for this article is retained by the author(s), with first publication rights granted to the journal.

This is an open-access article distributed under the terms and conditions of the Creative Commons Attribution license (http://creativecommons.org/licenses/by/4.0/). 